\title{
Financial Analysis of Lehman Brothers' bankruptcy
}

\author{
Zhiyue $\mathrm{Ma}^{1}$ \\ ${ }^{1}$ Chongqing Technology and Business University
}

\begin{abstract}
Under the U.S. subprime lending crisis, Lehman Brothers, with 158 year history, declared bankruptcy suddenly. It is not only related to the external factors like American financial innovation develops excessively and supervises disadvantageously, but also has certain inherent connections to its internal financial management goals. This article will give an in-depth analysis from the perspective of financial management goals of why Lehman Brothers bankrupted.
\end{abstract}

Keywords: Lehman Brothers, Financial management goals, shareholder wealth maximization

Has 158 year history "Lehman Brothers" is the U.S. fourth great Investment bank, who officially filed for Chapter 11 bankruptcy protection On September 15, 2008, because the relief program talks between Bank of America and Britain's Barclays Plc broke down. Lehman Brothers, the erstwhile masters in American finance industry, was driven into bankruptcy with more than 100 thousand creditors and 613 billion huge debts. This is not only related to the external factors like financial innovation develops excessively and supervises disadvantageously, but also has certain inherent connections to its internal financial management goals. This article will give an in-depth analysis from the perspective of financial management goals of why Lehman Brothers bankrupted.

\section{Shareholder wealth maximization: the realistic choice of Lehman Brothers' financial management goal}

Generally speaking, financial management goal is the expected results that the enterprise financing activities trying to realize under certain environment and condition, it directly reflects the changing financial environment and needs adjustment in accordance with changes in the environment. The goal decides the starting point and end result for financial decision for company financial management, also serve as the basic standard to judge financing activities. Therefore, to determine a reasonable goal of financial management is significant for optimizing cooperate financing behavior and making financial management to be in a virtuous. Currently, the main view points on goals of financial management are as follows: profit maximization, surplus maximization of each stock, shareholder wealth maximization, and company value maximization.

Lehman Brothers was officially established in 1850 , during the early establishment of the company, it is a small scale family business who are mainly engaged in commodities-trading like lucrative cotton trade, its financial management goal naturally is to maximize profit. It started from a small dry-goods store and then grew into one of Wall Street's investment giants and a national even world famous listed company. In accord- 
ance with the development, its financial management goal is transferred into shareholder wealth maximization. There are three factors accounting for this transformation: (1) In America, with the developed marketing economy, improved market economy system and capital markets, shareholder wealth maximization is easier to get better support from external environment of enterprise. (2) Comparing to profit maximization, shareholder wealth maximization is more scientific and more rational, because it considers the uncertainty, time value and shareholder' s capital costs. Shareholder wealth maximization is directly determined by stock price which is easy to quantify and operate in capital market.

Therefore, In a certain sense, shareholder wealth maximization is a realistic choice for Lehman Brothers' financial management goal.

\section{The internal cause of Lehman Brothers' bankruptcy: shareholder wealth maximization}

Shareholder wealth maximization is using appropriate financial management to bring shareholder more money. Compared to profit maximization, shareholder wealth maximization considers the time value of profits, relations between making profit and invested capital, to a certain extent, also eliminates short-sighted obsession with profits behavior in enterprise. When Lehman Brothers took shareholder wealth maximization as their financial management goal, company quickly grew up from an unknown small store into a world-famous Wall Street giant. However, taking shareholder wealth maximization as financial management goal also has some disadvantages including only caring shareholder's interests, just applying to listed company and focusing too much on stock price, so even Lehman Brothers wasn't immune to this once-in-a-century financial crisis. Shareholder wealth maximization made Lehman Brothers successful, but also broke it down.

\subsection{Under shareholder wealth maxi- mization, paying too much atten- tion on pursuing profit and ignor- ing operating risk directly lead Lehman Brothers to bankrupt}

During the early stage of Lehman Brothers, it was just a dry-goods store, then driven by the financial management goal of profit maximization, the firm entered the most profitable commodity futures trading, subsequently dealt in stock underwriting, securities trading financial investments and so on. During the seven years from 1899 to 1906, Lehman Brothers developed into one of the most powerful stake underwriter in New York. Every business transformationof Lehman Brothers was resulted from pursuing of maximum profit, while company excessively emphasizes on the gains and overlook risk control, which finally lead to its bankruptcy. During the following one hundred years after 1906, the firm survived from a series of disasters like American Great Depression in 1929 and oil shock caused by the forth Mideast war in 1973. Nevertheless Lehman Brothers who had a reputation of lasting forever could not escape the economic crisis in 2007 and collapsed. The apparent cause of Lehman Brothers' bankruptcy is excessive financial innovation and loose financial supervision, but in essence, it is because they one-sidedly focused on economic growth, disregarding negative consequences for risk. The deep engagement of CDO and CDS makes them ignore the huge risk of CDS market which is about four times that of American GDP. So it has to take the consequences of its actions. 


\subsection{Under shareholder wealth maxi- mization, paying too much atten- tion on stock price and pulling away from its core business accel- erated the bankruptcy of Lehman Brothers}

Shareholder wealth maximization believed company was established by shareholders' capital contribution, and the reason they start a company is to build wealth, as the owners of company, company undoubtedly should pursue shareholder wealth maximization. Under the condition of shareholding economy, wealth of shareholder is decided by the number of stocks and the market price of stocks. The key factor which influences shareholder wealth is stock price given the certain number of stocks. When stock price hits the highest, shareholder wealth reach the maximum. In order to maintain company's stock price at a relatively high level, Lehman Brothers has been taking $92 \%$ of company's after-tax profits to purchase its own stocks for seven years since 2000. Although this move helped raise the company's stock price, to maintain the superficial prosperity, also reduced the company's own cash holdings, lowered its ability to cope with risks. On the side, using the profit after tax to buy its own company rather than other's stock is undoubtedly a risky investment decision like "putting all eggs in one basket" and would not benefit the dispersion of investment risk. Caring too much about the short-term rise and fall of company stock results in company operation weak, brings about a shift on company's priorities, and caused the loss of economic foundations to maintain a high stock price.

\subsection{Under shareholder wealth maxi- mization, just caring sharehold- er's interest instead of all stake- holders internally caused Lehman Brothers' bankruptcy}

Since Lehman Brothers went to public in 1984, company's ownership and operation was separated, the operation class no longer holds company's stock or just partly holds the stock. Relationship between the ownership and operation is principal-agent relation, so two classes were formed in the company; they are shareholders (owners) and professional managers (operators). The shareholders entrusted professional managers to manage company with the goal of achieving shareholder wealth maximization. The results of business performance and evaluation of financial statements will reflect trustees' responsibility fulfillment as well as realization of the established financial goals. After going public, Lehman Brothers made profits in the 14 consecutive years and achieved $1103 \%$ shareholder return in 10 years. However, modern enterpriseis a combination of different kinds of contractual relationships including shareholder, creditors, management, staff, customer, government and other interested parties. Shareholder wealth maximization one-sidedly stresses the supremacy of shareholder wealth but neglect interest of other interested parties; finally generated the frequent inherent contradictions between relevant benefit main bodies. Low activity of employees brings about employees' weak sense of ownership, even when the employee share-holding rate reaches up to $37 \%$. In addition, the choice of shareholder wealth maximization made Lehman Brothers overlook the social responsibility that company should take. Then the contradictions between itself and the society partly could partly account for its bankruptcy. 


\subsection{Another reason caused Lehman Brothers 'bankruptcy is share- holder wealth maximization only applies to listed company}

In order to promote the competing ability of the Company, Lehman Brothers carried out a range of strategic recapitalization and reform management system in 1993. Like many Chinese companies, American Express, the parent company of Lehman Brothers, to support its listing, divested high quality assets and injected in listed companies. On the business front, core business and non-core business were separated, listed company and non-listed company operated separately. Such a method keeps listed company away from remaining independent from group-wide company, either in internal corporate administration or market operation. Therefore, the examination and evaluation to its performance should be carried at the height of the entire group of companies, instead of just looking at this subsidiary company's financial situation and operating results. Only the listed company has stock price, so the financial management goal of shareholder wealth maximization is applicable to it, while the parent company and other subsidiary companies do not. Therefore, the financial goal is unable to lead the whole group company to make right financial decision. On the contrary, the height of the entire group may mislead other non-listed companies in their financial management. This is another reason make Lehman Brothers ultimately fail.

\section{The inspiration on enterprise finan- cial management goal selection based on Lehman brothers' case}

\subsection{Inspiration on the importance of financial management goal}

The collapse of Lehman Brothers made us aware of how important it is to select the right financial management goal for company. Because financial management goal is the basic guideline for company financial management activities, is the fundamental objective that company should achieve, also is the starting point and the result of company financial management activities. Financial management goal will help a company decide to build what kind of financial management organization, to follow what financial management principles, to use what financial management method and to establish what financial index system. Financial management goal is the basic standard of financial decision-making, so every financial management activity is to achieve financial management the goal. As a result, through the theoretical analysis and practice, it is of great significance to choose the appropriate financial management goal.

\subsection{Inspiration on principles of for- mulating financial management goal}

The second inspiration of Lehman Brothers' bankruptcy to us is that company need to comply with the following principles when setting the financial management goal: (1) Value-oriented and risk control principle. Financial management goals not only inspire enterprises to create more profit and value, but also always remind the operator to control the risks; (2) Take broader stakeholders' interests into consideration rather than the minorities. Enterprise is a carries multistakeholder' s interest, and financial management is a process that coordinates the interests of all parties to avoid contradictory; (3) Consideration must be given to both suitability and universality. The operability of the financial management goals is as important as their scope of application; (4) Absolute stability and relative changes. Financial management goals will maintain absolute stability to 
develop enterprise' s long-term developmental strategy, but also adjust the goals in time to adapt environment changes.

\subsection{The inspiration of making a rea- sonable choice of enterprise fi- nancial management goal}

No matter what goals Lehman Brothers adherence to, like shareholder wealth maximization or production value maximization, profit maximization, enterprise value maximization, even the stakeholder interests maximization which is a nonmainstream financial management goal, they all have their own advantages and drawbacks. So we suggest that when choosing a financial management goal, it is appropriate to have two or more goals at the same time by making use of the respective advantages and overcoming the disadvantages. Some principles need to be considered when choosing the financial management goals combination: (1) The combined financial management goals must be beneficial to enterprise' $\mathrm{s}$ economic situation, enterprise' $\mathrm{s}$ ability in three aspects (operation capacity, debt paying ability and profitability); and maintenance of the society' s overall interests. (2) The combined financial man- agement goals should have priorities to avoid the various contradictions and conflicts between different financial management goals.

\section{References}

[1] Chengde Luo and Jingjing Zhou, "Cooperate financial management goal research overview Ins and Outs of the Joint Conference on Information Sciences", Communication of Finance and Accounting. Money management version, pp. 56-57, (12) 2008.

[2] Wei Chen, "The discuss on the financial goals of stakeholder interests maximization - based on the theory of stakeholder and the perspective of system science", Accounting Research, pp. 63-67, (4) 2006.

[3] Guohua Chang, "comparative study on financial management goals", Friends of Accounting, pp. 18-19, (2) 2008.

[4] Jiachao Lin, "China's current financial management goals selection discuss on the necessity of take stakeholder interest maximization as financial management goal', Times Finance, pp. 172, (11) 2006. 